\title{
Metacognitive Level Analysis of High School Students in Mathematical Problem-Solving Skill
}

\author{
Fatma Erya Santoso 1,* , E. Elvis Napitupulu², Zul Amry² \\ ${ }^{1}$ Universitas Negeri Medan, Posgraduate, Medan, Indonesia \\ ${ }^{2}$ Universitas Negeri Medan, Medan, Indonesia \\ *Corresponding author: fatma.erya@gmail.com
}

Received September 18, 2019; Revised October 28, 2019; Accepted December 05, 2019

\begin{abstract}
This study aims to analyze: the level of students' metacognition in mathematical problem-solving skills. The subjects of this study were students of grade X at Private Madrasah Aliyah Al - Asy'ariyah Medan Krio. The objects of this research were students' metacognition level and mathematical problem-solving skills. The results showed that: the level of students' metacognition in mathematical problem-solving skills of 32 students were: (1) Students with high levels of problem-solving skills were at the level of metacognitive strategy use; (2) Students with the medium level of problem-solving skills were at the level of metacognitive aware use; (3) Students with low levels of problem-solving skills were at the level of metacognitive tacit use.
\end{abstract}

Keywords: analysis, metacognition, mathematical problem-solving skill

Cite This Article: Fatma Erya Santoso, E. Elvis Napitupulu, and Zul Amry, "Metacognitive Level Analysis of High School Students in Mathematical Problem-Solving Skill." American Journal of Educational Research, vol. 7, no. 12 (2019): 919-924. doi: 10.12691/education-7-12-4.

\section{Introduction}

Mathematics has a crucial role in life because mathematics is needed in all disciplines. Considering the importance of mathematics in life, in the Indonesian curriculum, mathematics is one of the subjects that exist at all levels of education, ranging from elementary to college level. According to [1], "Mathematics needs to be taught to students because (1) it is always used in all aspects of life, (2) all fields of study require appropriate mathematical skills, (3) a means of communication that is strong, concise, and clear, (4 ) can be used to present information in a variety of ways, (5) improve the ability to think logically, accuracy, and awareness of the room, and (6) provide satisfaction with efforts to solve challenging problems ".

The learning objectives of mathematics formulated by the National Council of Teachers of Mathematics [2] are: (1) learning to communicate (mathematical communication), (2) learning to reason (mathematical reasoning), (3) learning to solve problems (mathematical problem solving), (4) learning to link ideas (mathematical connections), (5) the formation of a positive attitude towards mathematics (positive attitudes toward mathematics).

One of the goals of learning mathematics in the 21st century is that students can have higher-order thinking skills. The process of teaching and learning mathematics today is more directed at the ability to solve problems. It is in line with the recommendation of [2] that the focus of mathematics learning in school is problem-solving.
According to [3], problem-solving is an attempt to find a way out of difficulty and achieve goals that cannot be achieved immediately.

Problem-solving is one type of intellectual skills that, according to [4], is higher in degree and more complex than other types of intellectual skills. [4] argues that in solving problems, complex rules or high-level rules are needed, and high-level rules can be achieved after mastering well-defined rules and concepts. Likewise, defined rules and concepts can be mastered if supported by a concrete understanding of concepts. After that, in order to understand the concrete concepts, skills in differentiating are needed.

Reference [5] also states that solving mathematical problems will help students to improve their ability to analyze and use them in different situations. Problem-solving also helps students in learning with facts, skills, concepts, and principles through the illustration of the application of mathematical objects and the links between these objects. In solving problems, students are not only required to be able to find solutions to the problems, but the stage of thinking in problem-solving is also an important thing to be considered by educators in developing students' problemsolving abilities.

Lester [6] states that the primary purpose of teaching problem-solving in mathematics is not only to equip students with a set of skills or processes, but rather to enable students to think about what they think. Thinking about what is thought, in this case, is related to students' awareness of their ability to develop various ways that might be done in solving problems. According to [6], 
the process of realizing and organizing students' thinking, known as metacognition, includes thinking about how students make approaches to problems, choosing strategies used to find solutions, and asking themselves about the problem.

[7] defines, "metacognition is thinking about our thinking, and it comprises of the following three important aspects: knowledge about our thought processes, control or self-regulation, and belief and intuition." [8] provides a more complex explanation of metacognition, "definition of metacognition, to include the knowledge of one's own cognitive and affective processes and states as well as the ability to consciously and deliberately monitor and regulate those processes and states." Metacognition has an important role in learning mathematics especially in developing students' mathematical problem-solving abilities.

The importance of metacognition related to problem-solving skills in mathematics learning was stated by [9] that the implications of metacognition are not only in mathematics learning but in monitoring students' thought processes to develop positive character and personality formation that can be developed in each learning. Students are said to have metacognition if, in mathematical problem-solving abilities students can fulfill the following stages: (1) compiling an action plan, (2) monitoring problemsolving actions, and (3) evaluating problem-solving actions [10].

Based on the results of the 2012 PISA study [11], Indonesia ranked 64 out of 65 participating countries, or in other words, ranks second lowest of all PISA participating countries. It surveyed with an average score of Indonesian students' mathematical abilities of 375 . The score was below the international average score of 494. The factors that caused the low achievement of Indonesian students in PISA were the weak ability to solve non-routine or highlevel problems. The questions tested in PISA consisted of 6 levels (lowest level 1 and highest level 6), and the questions that were tested were contextual in which the problems were taken from the real world. Students in Indonesia were only accustomed to routine questions at level 1 and level 2. It can be concluded that metacognition in Indonesian students' mathematical problem-solving abilities is low.

Metacognition can be developed through problem-solving skills. Problem-solving is done by involving awareness of the thought process and the ability to self-regulate, so as to enable the building of a strong and comprehensive understanding of the problem along with logical reasons. Students are said to be able to solve problems if in solving problems-solving problems do 4 stages, namely: (1) Understanding the problem; (2) Devising a plan; (3) Carrying out a plan; and (4) looking back [3].

The stages of problem-solving by Polya, are the stages that have significant impacts on the regulation of cognition in problem-solving. Departing from Polya's ideas about the stages of problem-solving, it can be said that all the stages proposed lead to students' awareness and regulation of the processes implemented to obtain appropriate solutions.

Based on the description above, the purpose of this study is to determine the level of metacognition students in mathematical problem-solving skills.

\section{Method}

This type of research was qualitative research. The subjects of this study were students of grade X IPA - 2 at MAS Al-Asy'ariyah Medan Krio. The objects of this research were students 'metacognition level and mathematical problem-solving abilities. The instruments used consisted of: a test of mathematical problem-solving ability with metacognition questions and interview guidelines. The purpose of this study was to analyze the level of metacognition of students in mathematical problem-solving skills and metacognition difficulties of students in mathematical problem-solving skills in problem-based learning in MAS Al-Asy'ariyah Medan Krio.

\section{Results}

After learning on the material equation and inequality of absolute value of linear one variable, the meeting continued by giving a test to see students' mathematical problem-solving skills. Corrected answer sheets based on scoring guidelines were judged based on valid, objective, fair, integrated, comprehensive, and continuous, systematic, criteria-based, accountable principles [12]. Based on the corrected results (attachment), the level of mathematical problem-solving skills is presented as follows:

Table 1. Level of Students Mathematical Problem-Solving Skill

\begin{tabular}{|c|c|c|c|c|}
\hline No & Score Interval & $\begin{array}{c}\text { The number } \\
\text { of students }\end{array}$ & Percentage & Category \\
\hline 1 & $3,18<$ SPMM $<4,00$ & 8 & $25,00 \%$ & High \\
\hline 2 & $2,18<$ SPMM $<3,17$ & 15 & $48,88 \%$ & Medium \\
\hline 3 & $1,00<$ SPMM $<2,17$ & 9 & $28,13 \%$ & Low \\
\hline
\end{tabular}

Based on Table 1 above, it can be seen that the percentage of problem-solving skills of high-ability students is lower than medium and low abilities. The results of the 32 students 'mathematical problem-solving skill test obtained the level of students' mathematical problem-solving abilities which spread over three levels, are presented in Diagram 1 below:

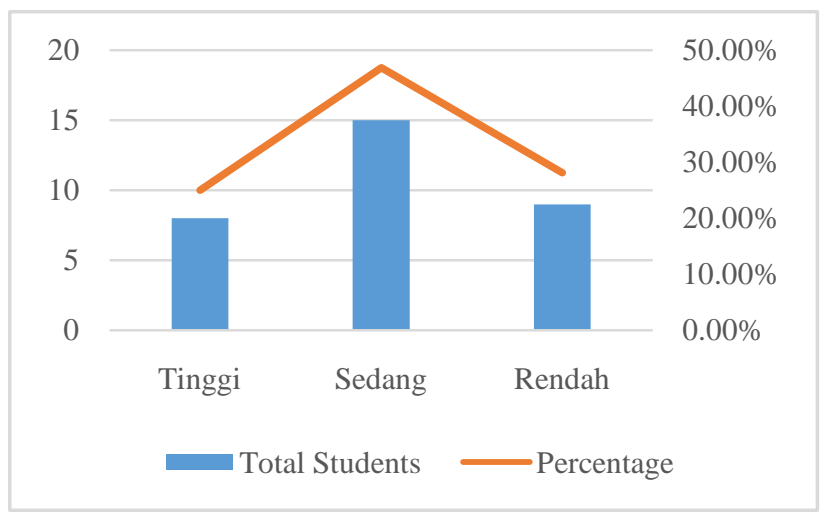

Figure 1. Diagram Level of Students Mathematical Problem Solving Skills

Of the 32 students, it turns out that the level of mathematical problem-solving skills of medium-capable 
students has the highest proportion, followed by low-ability students and subsequently high-ability students. Thus, the level of mathematical problem-solving skills of students with high ability as is $25.00 \%$, the medium ability is $48.88 \%$, and low ability is $28.13 \%$.

Based on the results of students 'problem-solving skills, the researchers looked at students' metacognition in problem-solving. Students' metacognition in mathematical problem-solving skills was obtained from tests given after learning. The results of students' metacognition are presented in Table 2 below:

Table 2. Students' Metacognitive Levels

\begin{tabular}{|c|c|c|c|}
\hline No & Level of Metacognition & The number of students & Percentage \\
\hline 1 & Reflective Use & 1 & $3,13 \%$ \\
\hline 2 & Strategic Use & 6 & $18,75 \%$ \\
\hline 3 & Aware Use & 15 & $46,88 \%$ \\
\hline 4 & Tacit Use & 10 & $31,25 \%$ \\
\hline
\end{tabular}

Based on Table 2 above, it appears that the percentage of the level of reflective use has a lower proportion than the level of metacognition of strategic use, tacit use, and aware use. The results of the mathematical metacognition of students are 32 people. It is obtained the level of mathematical metacognition of students which spread over the four levels of metacognition, presented in Figure 2 below:

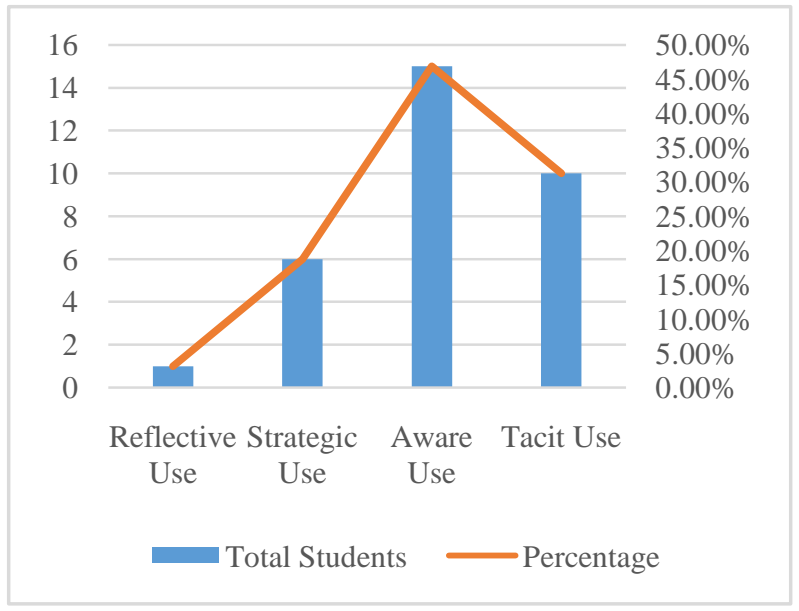

Figure 2. Diagram of Students' Mathematical Metacognitive Levels

Based on Figure 2 above, students who have metacognition with the level of reflective use are only 1 student (3.13\%), the level of strategic use is 6 students (18.75\%), the level of aware use is 15 people (46.88\% ), and tacit use level of 10 people (31.25\%).

According to Swartz and Perkins [13], the level of awareness of one's thinking when solving a problem is divided into four levels, namely: (1) tacit use, (2) aware use, (3) strategic use, and (4) reflective use. Students' thinking awareness was measured based on the metacognition indicator, according to [10], namely (1) the planning stage, (2) the monitoring phase, and (3) the evaluation phase.

In Figure 2 above, there is only one student who is at the level of reflective use. It means as a whole, at the stage of thinking awareness, students can solve problems according to the stage of awareness of thinking well. Six students are at the level of strategic use. It means as a whole, in the stage of thinking awareness, students can solve problems according to their thinking awareness quite well. Fifteen students are at the level of aware use. It means as a whole, at the stage of thinking awareness, students can solve problems according to their thinking awareness poorly. Ten students are at the level of tacit use. It means as a whole, in the stage of thinking awareness, students are not able to solve problems in accordance with the awareness of thinking well.

Students with high category problem-solving skills have a good level of metacognition. It can be seen based on students' answer sheets for problem-solving ability tests and metacognition questions. These results can be seen in Figure 3 for the following test 2 questions:

\section{Test 2:}

The average time it takes a group of athletes to run 2 miles is 16 minutes. Note that the athlete's running time can be faster or 2 minutes slower than this average time. Write an equation to display this situation and determine the fastest and longest time taken by a group of athletes.

\section{Figure 3. Problem-Solving Skill Test Questions}

Based on the results of the field, from 32 students, only one student answered completely, and correctly, 22 students answered incomplete, and nine people answered incomplete and many errors. Following is one of the answers of students with high mathematical problemsolving abilities, presented in Figure 4:

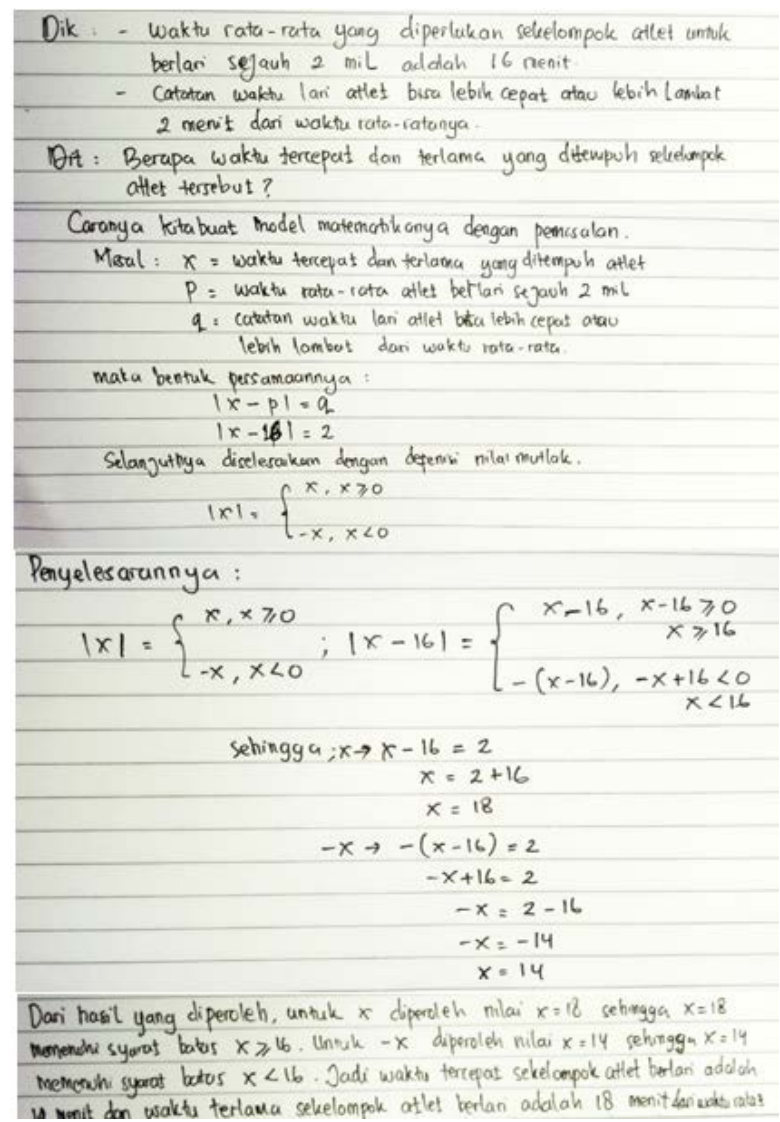

Figure 4. The Students’ Answer of Mathematical Problem Solving Skills Test 
Based on the results of the mathematical problem solving answers of high-skilled students in Figure 3, students are able to carry out the stages of mathematical problem solving, according to Polya, namely, understanding the problem by understanding what is known and asked from the problem by explaining the problem in the form of their own language. At the stage of making a completion plan (devise a plan) based on information provided, students can make a mathematical model and make a linear absolute value equation of one variable to find the fastest and longest time an athlete to run as far as 2 miles. At the stage of carrying out a problem-solving plan (carry out a plan), students use a plan that has been prepared and do the calculations correctly. In the 'look back' stage, students can recheck the results obtained or interpret the results obtained in the context of the problem by giving their arguments.

For students with high ability problem-solving answers, an analysis of the metacognition results was also carried out. High ability student answer sheets would be analyzed based on metacognition stages, according to [10], namely the stage of developing a solution plan, the stage of monitoring problem solving, and the stage of evaluating problem-solving. The answer to students' metacognition in solving problems, in high-ability students, according to the metacognition indicators is as follows:

\section{1) Developing a solution plan}

a. To solve this problem, what initial knowledge/material can help me solve the above problem?

b. What is the first step that I will take after reading the question?

c. How long will I complete this problem in full? Why is that?

Figure 5. Mathematical Metacognition Questions

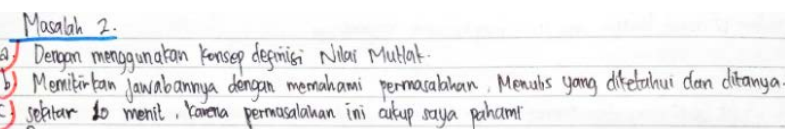

Figure 6. The Students’ Answer of Mathematical Metacognition

Based on the results of the students' metacognition answers in Figure 6, it is found that high-ability students are able to answer appropriately for the stage of developing a problem-solving plan on the criteria for achieving aspects of the indicators, namely (a) students who are at the level of strategic use are able to explain the prerequisite material in solving problems correctly, although not complete, (b) students who are at the level of strategic use are able to explain plans to solve problems appropriately but are incomplete, and (c) students who are at the level of reflective use are able to determine plans for the use of time and give reasons for the use of time appropriately.

\section{2) Monitoring problem-solving}

Based on the results of the students' metacognition answers in Figure 8, it is found that high-ability students are able to answer appropriately for the stage of monitoring problem solving on the criteria for achieving aspects of indicators, namely (d) students who are at the level of reflective use are able to explain the reason for rereading the questions and show seriousness in understand the problem to be solved by themselves, (e) students who are at the level of strategic use are able to explain how to solve problems that will be used appropriately but incomplete, and (f) students who are at the level of reflective use are able to explain the reasons that the completion process is done well and thoroughly with the language of high confidence.

d. What should I do if after reading the problem I do not understand the problem given?

e. How do I resolve the above problem?

f. Why am I sure that the answer process I made is correct? Why is that?

Figure 7. Mathematical Metacognition Questions

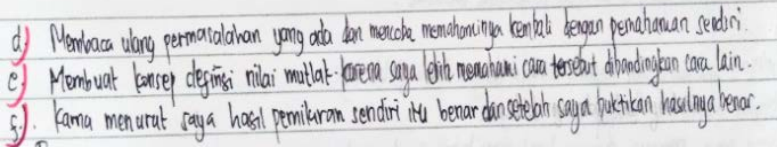

Figure 8. Students' Answer of Mathematical Metacognition

\section{3) Evaluating problem-solving actions}

g. Why did I use this method to solve the problem above?

h. How did I recheck the truth of the answers I have written?

i. What did I learn after solving the problem above?

Figure 9. Mathematical Metacognition Questions

$$
\begin{aligned}
& \text { g. Karma konsep definiri nilai mullat ini memang cara unut meniawab permasalahan ini. }
\end{aligned}
$$

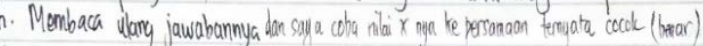

$$
\begin{aligned}
& \text { i. Saya memplajari bahura consep definisi ini ara unhte merijauab sebuah permasabahan. }
\end{aligned}
$$

Figure 10. Students' Answers of Mathematical Metacognition

Based on the results of the students' metacognition answers in Figure 10, it is found that high-ability students are able to answer appropriately for the stage of evaluating problem-solving actions on the criteria for achieving aspects of the indicator, namely (g) students who are at the level of reflective use are able to explain the reason for the solving made based on their understanding of what they are learning, (h) students who are at the level of reflective use are able to interpret the results of the answers obtained in accordance with the context of the problem with the mathematical model and provide arguments appropriately, (i) students who are at the level of strategic use are able to explain in part what they have learned from solving problems that have been made correctly.

\section{Discussion}

Problem-solving skills after learning can be described and discussed according to research data for each level of mathematical problem-solving skills. Based on the written results that have been done, it can be concluded that the percentage of problem-solving abilities of high-ability students is lower than medium ability and low ability. High-ability students were $25.00 \%$, students with moderate abilities were $48.88 \%$, and low-ability students were $28.13 \%$.

The results of students' mathematical problem-solving skills data are also followed by the results of their 
metacognition. Students with high levels of problemsolving skills, which were at the level of strategic use metacognition, were $21.88 \%$. It means that students have good awareness at several stages of metacognition. The stages include students are able to write things that are known and things that are asked correctly; students are able to represent problems into mathematical models; students are able to choose and implement appropriate strategies to solve problems; do calculations correctly; and are able to interpret the results of the settlement in accordance with the context of the initial problem.

Students with a medium level of problem-solving skills, which were at Aware Use metacognition level were 46.88\%. It means that students have enough awareness in several stages of metacognition. They include students can write things that are known and things that are asked correctly; students can represent problems in the mathematical model; students can choose and implement the right strategy to solve the problem but have not been able to do the calculations correctly.

Students with low problem-solving skills who were at Tacit Use metacognition level were 31.25\%. It means that students do not have a good awareness in several stages of metacognition, i.e., students are not able to write things that are known and things that are asked correctly, students are not able to represent problems into the mathematical model, students are not able to choose and implement the right strategy to solve the problem, do not do the calculations correctly, and do not interpret the results of the settlement in accordance with the context of the initial problem.

Students who were at the Strategic Use metacognition level had a lower proportion than students who were at the Aware Use and Tacit Use level of metacognition. Based on these results, it can be concluded that the average problem-solving skills of class X MAS Al-Asy'ariyah Medan Krio students are in the medium category. Research data follow that the average level of metacognition of grade X MAS Al-Asy'ariyah Medan Krio students is in the Aware Use category. Based on this result, we can see that there is a relationship between students 'mathematical problem-solving skills with students' mathematical metacognition. In other words, students who have good mathematical problem-solving skills will also have good metacognition. Vice versa, students with low mathematical problem-solving skills will have low metacognition as well. The results of this study reinforce the results of previous studies conducted by [14], who stated that "there is a positive linear relationship between metacognitive awareness and cognitive skills."

The results of research on students' metacognition processes in solving mathematical problems show that when developing plans or action strategies, students with high academic abilities are aware of their thought processes by identifying information given in the problem and restating it in a more operational form by writing out the known variables in the problem. It is in line with the research of [15], which states that only students with high academic ability can properly evaluate or assess the results of their written work so that only students in this category can answer all problem questions with the correct result.
[16] conducted a study with the results showed that in metacognitive knowledge, students who solve problems correctly are not aware of their strengths. Whereas in the metacognitive experience, students do not ask themselves about the steps that must be taken and do not estimate how long it will take to carry out the completion plan. Furthermore, in metacognitive knowledge, students who make mistakes in solving mathematical problems are not aware of their strengths and weaknesses, do not realize the knowledge that can be used, and do not know the reasons for using a strategy. Whereas in metacognitive experiences students do not ask themselves about the steps that must be done, do not realize there is an error in understanding the problem, do not realize how well the results work in understanding the problem, do not know how the correct strategy, do not realize there is an error in preparing the strategy, do not realize how well the strategy is used, do not estimate how long it will take, do not realize there are mistakes in carrying out the plan of completion, do not realize how well the results of their work in carrying out the plan of completion, are not aware of the mistakes made in solving mathematical problems and do not realize how well they work in solving mathematical problems..

\section{Conclusion}

Students who are at a high level of problem-solving skills are at the level of metacognition of strategic use. They show awareness of their abilities, can know what they are going to do and can select strategies or special skills to solve problems. Students who are at the medium level of mathematical problem-solving skills are at the level of metacognition aware use. They are aware of their weaknesses and begin to realize that they must use a problem-solving step by explaining why they chose that step. Students who are at a low level of mathematical problem-solving skills are at the level of tacit use metacognition. They are less aware of their abilities, are less aware of their weaknesses when solving problems, and apply strategies in solving problems without specific awareness and origin in answering problem-solving without regard to the truth of the answers.

\section{References}

[1] Cockcroft, W.H. 1982. Mathematics Counts: Report of the Committee of Inquiry into the Teaching of Mathematics in Schools under the Chairmanship of Dr WH Cockcroft. London: Her Majesty's Stationery Office.

[2] NCTM., 2000. Principles and Standars for School Mathematics. Reston: VA, the National Council of Teachers of Mathematics, Inc.

[3] Polya, G. 1971. How to solve It. Second Edition. New Jersey: Princeton University Press.

[4] Gagné, R. M., Briggs, L. J. dan Wager, W.W .1992. Principles of Instructional Design ( ${ }^{\text {nd }}$ ed). Orlando: Holt, Rinehart and Winstone, Inc.

[5] Bell, F. H. 1978. Teaching and Learning Mathematics in Secondary School. New York: Wm. C. Brown Company Publisher.

[6] Gartman, S., and Freiberg, M. 1995. Metacognition and Mathematical Problem Solving: Helping Students to Ask The Right Questions, The Mathematics Educator, Volume 6 Number 1, hal: 9-13. 
[7] Schoenfeld, A. H. 1992. Learning to think mathematically: Problem solving, metacognition, and sense-making in mathematics. In D. Grouws (Ed.), Handbook for Research on Mathematics Teaching and Learning (pp. 334-370). New York: MacMillan.

[8] Hecker, D. J., Dunlosky, J., Graesser A. C. 1998. Handbook of Metacognition in Education. New York: Routledge is an imprint of the Taylor \& Francis Group.

[9] Chairani, Z. 2016. Metakognisi Siswa dalam Pemecahan Masalah Matematika. Yogyakarta: Deepublish.

[10] Flavell, J.H. 1979. Metacognition and cognitive monitoring: A new area of cognitive-developmental inquiry. American Psychologist, Volume 34, pp. 906 - 911.

[11] Organisation for Economic Co-operation and Development (OECD). 2018. PISA 2015 Result in Focus. Paris: OECD Publishing.
[12] Permendikbud No. 23: 2016. Lampiran 3 Pedoman Mata Pelajaran MTK.

[13] Fisher, R. 1998. Thinking about Thinking: Developing Metacognition in Children. Early Child Development and Care, Volume 141, pp. 1-15.

[14] Amin, I., Sukestiyarno, L. Y. 2015. Analysis Metacognitive Skills On Learning Mathematics In High School. International Journal of Education and Research. Vol. 3 No. 3 March 2015.

[15] Kartika, L. D., Riyadi, Sujadi, I. 2015. Proses Metakognisi Dalam Pemecahan Masalah Matematika Pada Siswa Kelas XI di SMA Negeri Banyumas. Jurnal Elektronik Pembelajaran Matematika. ISSN: 2339-1685 Vol.3, No.9, hal 1021-1034 November 2015.

[16] Alfiyah, N., Siswono, T. Y. E. 2014. Identifiksi Kesulitan Metakognisi Siswa Dalam Memecahkan Masalah Matematika. Jurnal Ilmiah Pendidikan Matematika. Vol 3, No. 2 hal: 131-138.

(C) The Author(s) 2019. This article is an open access article distributed under the terms and conditions of the Creative Commons Attribution (CC BY) license (http://creativecommons.org/licenses/by/4.0/). 